\title{
ADAPTATION OF FOREIGN EXPERIENCE IN ENSURING FOOD SECURITY TO RUSSIAN CONDITIONS
}

\author{
Aleksandr V. Ishkhanov \\ Kuban State University, Krasnodar, Russian Federation \\ Elena F. Linkevich \\ Kuban State University, Krasnodar, Russian Federation
}

\begin{abstract}
One of the most significant criteria characterizing the effectiveness of the country's food security system is ensuring access of the entire population (including the poor) to the necessary amounts of food. To solve the problem of poverty and malnutrition, new approaches that involve strengthening government regulation, attracting resources from commercial companies, and increasing the efficiency of public socially-oriented organizations are needed. The article proposes a large-scale state program that provides support to the country's poor, with the active participation of business structures and Russian food banks. The main directions of the state program are determined taking foreign experience in supporting the poor, as well as the specifics of the development of the Russian economy and social sphere into account. Particular attention is paid to the changes in the tax legislation of the Russian Federation, aimed at increasing the interest of private enterprises in the implementation of the program to support the low-income population. The proposed amendments are especially relevant in the face of the deteriorating economic situation caused by the COVID-19 pandemic. The developed set of measures complies with the provisions of the updated Food Security Doctrine of 2020 and can be an addition to the strategies being implemented to improve the efficiency of the food security system in the Russian Federation.
\end{abstract}

Key words: food security, food supply, food availability, food problems, problems of poverty and malnutrition.

Citation. Ishkhanov A.V., Linkevich E.F. Adaptation of Foreign Experience in Ensuring Food Security to Russian Conditions. Vestnik Volgogradskogo gosudarstvennogo universiteta. Ekonomika [Journal of Volgograd State University. Economics], 2021, vol. 23, no. 2, pp. 85-96. (in Russian). DOI: https://doi.org/10.15688/ek.jvolsu.2021.2.7

\section{АДАПТАЦИЯ ЗАРУБЕЖНОГО ОПЫТА ОБЕСПЕЧЕНИЯ ПРОДОВОЛЬСТВЕННОЙ БЕЗОПАСНОСТИ К РОССИЙСКИМ УСЛОВИЯМ}

\section{Александр Владимирович Ишханов}

Кубанский государственный университет, г. Краснодар, Российская Федерация

\section{Елена Федоровна Линкевич}

Кубанский государственный университет, г. Краснодар, Российская Федерация 
Аннотация. Одним из наиболее значимых критериев, характеризующих эффективность системы продовольственной безопасности страны, является обеспечение доступа всего населения (в том числе малоимущих) к необходимым объемам продуктов питания. Для решения проблем бедности и недоедания необходимы новые подходы, предусматривающие усиление государственного регулирования, привлечение ресурсов коммерческих компаний, а также повышение эффективности деятельности общественных социально ориентированных организаций. В статье предложено проведение широкомасштабной государственной программы, обеспечивающей поддержку малоимущего населения страны, при активном участии бизнес-структур и российских благотворительных продовольственных фондов. Основные направления государственной программы определены с учетом зарубежного опыта по поддержке малоимущих слоев населения, а также специфики развития российской экономики и социальной сферы. Особое внимание в статье уделено изменениям в налоговом законодательстве РФ, направленным на повышение заинтересованности частных предприятий в реализации программы поддержки малообеспеченного населения. Предлагаемые поправки особенно актуальны в условиях ухудшения экономической ситуации, обусловленной пандемией вируса COVID-19. Разработанный комплекс мер соответствует положениям обновленной Доктрины продовольственной безопасности 2020 г. и может стать дополнением к реализуемым стратегиям по повышению эффективности системы обеспечения продовольственной безопасности РФ.

Ключевые слова: продовольственная безопасность, продовольственное обеспечение, доступность продовольствия, продовольственные проблемы, проблемы бедности и недоедания.

Цитирование. Ишханов А. В., Линкевич Е. Ф. Адаптация зарубежного опыта обеспечения продовольственной безопасности к российским условиям // Вестник Волгоградского государственного университета. Экономика. -2021. - Т. 23, № 2. - С. 85-96. - DOI: https://doi.org/10.15688/ek.jvolsu.2021.2.7

\section{Введение}

Проблема продовольственной безопасности остается актуальной для человечества на протяжении всего его существования. Подходы ученых различных экономических школ к решению проблем, связанных с продовольственной безопасностью, различаются. Так, многие российские эксперты по вопросам экономики сельского хозяйства связывают продовольственную безопасность с самообеспечением [Буланов, 2007; Ибрагимов и др., 2010; Кудряшова, 2009, с. 42-45]. С позиции других авторов, основой достижения высокого уровня продовольственной безопасности является стабильность развития экономики [Черняков, 1998; Шагайда, 2015]. Исследованию влияния самых различных экономических, политических и социальных факторов на продовольственную безопасность посвящено огромное количество научных трудов ученыхэкономистов [Коваленко, 2013; Носов и др., 2020; Основы экономической безопасности ... , 1997; Серова, 2004; Хромов, 1999].

В целом ученые сходятся во мнении, что высокий уровень продовольственной безопасности предполагает постоянную физическую и экономическую доступность для всего населения страны достаточного количества необходимой и безопасной для здоровья пищи.
Создание условий, обеспечивающих высокий уровень продовольственной безопасности, является одной из главных целей государственного регулирования. При этом проблема недоедания остается неразрешимой не только для развивающихся, но и для большинства развитых стран даже при наличии необходимых продовольственных ресурсов, высоком уровне развития аграрной отрасли и экономики в целом. В каждой стране мира (кроме Сингапура) часть жителей недополучает необходимого количества пищи. Россия не является исключением.

Проблема доступности продуктов питания в необходимых объемах для всех групп российского населения окончательно не решена, поэтому требуются дополнительные меры, направленные на поддержку малоимущих. Данные меры приобретают особую значимость в условиях ухудшения экономической ситуации, обусловленной пандемией вируса COVID-19.

\section{Государственная политика обеспечения продовольственной безопасности в России}

В 2020 г. принята новая Доктрина продовольственной безопасности, основные положения которой предопределили разработку комплексных программ, направленных на 
обеспечение устойчивого развития аграрной и пищевой промышленности, повышение эффективности системы обеспечения населения продуктами питания, а также на борьбу с бедностью (что, соответственно, предполагает решение проблемы недоедания).

Согласно Доктрине, продовольственная безопасность предполагает гарантию физической и экономической доступности продуктов питания для каждого жителя страны в объемах, необходимых для здорового и активного образа жизни [Указ Президента РФ ... , 2020]. При этом по данным, представленным Международным исследовательским институтом продовольственной политики в ежегодно публикуемом издании, доля российского населения, подверженного риску недоедания, составляет около 2,5 \%. Распространенность истощения у детей в возрасте до пяти лет составляет $3,5 \%$, а задержки роста - 9,5 \% (табл. 1) [Международный исследовательский институт ..., 2021].

Следует признать, что за последние 20 лет проблема экономической доступности продовольствия для всего населения РФ окончательно не решена. Кроме того, экономический спад, обусловленный пандемией вируса COVID-19, способствовал увеличению числа россиян, живущих за чертой бедности. Согласно данным Федеральной службы государственной статистики, количество россиян, имеющих доходы ниже прожиточного минимума, в 2020 г. увеличилась примерно на 200 тысяч и составила 18,6 млн человек (12,6 \% населения) [Федеральная служба государственной статистики, 2021].

Комплекс мер, направленных на повышение уровня продовольственной безопасности
России, должен быть существенно расширен. При этом целесообразно применение уже имеющегося зарубежного опыта.

Для повышения эффективности российской системы обеспечения продовольственной безопасности необходимо:

1. Усиление регулирующей роли государства.

2. Привлечение ресурсов коммерческих компаний.

3. Повышение эффективности деятельности российских банков продовольствия.

В настоящее время требуются новые подходы к повышению эффективности российской системы продовольственной безопасности. Необходимо формирование условий, обеспечивающих заинтересованность предпринимательских структур в поддержке наиболее нуждающихся групп населения.

\section{Зарубежный опыт по привлечению} ресурсов коммерческих компаний для поддержки малоимущего населения

Исследование зарубежного опыта в области обеспечения продовольственной безопасности имеет особую значимость для России, так как позволяет оценить положительные и отрицательные последствия применения тех или иных инструментов государственного регулирования для экономики, а также для социальной сферы страны.

Особо интересны стратегии развитых стран, применяемые для решения проблемы недоедания среди малоимущих. Например, в США с шестидесятых годов прошлого века

Таблича 1

Динамика Глобального индекса голода и используемых для его расчета показателей за период с 2000 по 2020 г. для РФ

\begin{tabular}{|l|c|c|c|c|}
\hline \multicolumn{1}{|c|}{ Показатель } & \multicolumn{4}{|c|}{ Год } \\
\cline { 2 - 5 } & 2000 & 2006 & 2012 & 2020 \\
\hline Глобальный индекс голода & 10,0 & 6,8 & 6,0 & 5,2 \\
\hline $\begin{array}{l}\text { Распространенность недоедания } \\
\text { среди населения, \% }\end{array}$ & 5,1 & не более 2,5 & не более 2,5 & не более 2,5 \\
\hline $\begin{array}{l}\text { Уровень смертности детей в возрас- } \\
\text { те до 5 лет, \% }\end{array}$ & 1,9 & 1,3 & 1,0 & 0,7 \\
\hline $\begin{array}{l}\text { Распространенность истощения у } \\
\text { детей в возрасте до 5 лет, \% }\end{array}$ & 4,1 & 3,4 & 3,2 & 3,5 \\
\hline $\begin{array}{l}\text { Распространенность задержки роста } \\
\text { у детей в возрасте до 5 лет, \% }\end{array}$ & 16,7 & 12,8 & 12,0 & 9,5 \\
\hline
\end{tabular}

Примечание. Составлено автором по: [Международный исследовательский институт ... , 2021]. 
действует федеральная программа продовольственных купонов. Цель программы - решить проблему недоедания малообеспеченного населения, не создавая иждивенческих настроений. Малоимущим семьям предоставлена возможность получения купонов для приобретения продовольственных продуктов в зарегистрированных магазинах. Американцы трудоспособного возраста, получающие помощь, должны иметь работу или быть зарегистрированными на бирже труда. Схожие программы действуют во многих странах, при этом финансирование осуществляется за счет государства, что увеличивает нагрузку на бюджет.

Стратегии многих стран в обеспечении продовольственной безопасности предусматривают масштабное привлечение коммерческих структур. Например, программа «Нулевой голод» Бразилии предопределила активное участие частных предприятий в решении проблем бедности и недоедания.

Актуальной для РФ является адаптация зарубежного опыта к решению проблемы бедности и недоедания посредством более активного привлечения продовольственных банков и коммерческих структур. Во многих странах мира через банки продовольствия в пользу малоимущих перераспределяются пищевые продукты с истекающим сроком годности. Как правило, передача продуктов питания населению самими банками продовольствия не осуществляется. Для налаживания связей с нуждающимися привлекаются благотворительные организации и социальные учреждения, которым банки продовольствия доставляют пищевые продукты. Затраты на услуги по перевозке и сортировке продуктов с истекающим сроком годности обычно оплачиваются за счет пожертвований частых лиц и организаций.

Деятельность продовольственных банков помогает снизить остроту не только продовольственной, но и экологической проблемы, так как предотвращает образование пищевых отходов. По данным Продовольственной и сельскохозяйственной организации $\mathrm{OOH}$ (ФАО ООН), на разных стадиях производства и потребления в отходы поступает более трети пищевых продуктов. В среднем на одного человека в год потери продовольственной продукции составляют:
- в странах Западной Европы - до 95 кг;

- в США - до 115 кг;

- в России - до 56 кг;

- в странах Африки и Юго-Восточной Азии - от 6 до 11 кг [Food and Agriculture Organization ..., 2021].

Снижение остроты продовольственной проблемы и сокращение потерь пищевых продуктов в настоящее время приобретают особую значимость, поэтому во многих странах мира всячески поощряется деятельность банков продовольствия, а также других общественных организаций, перераспределяющих продукты питания с истекающим сроком годности малообеспеченным группам населения. Например, в Германии существует объединение «Tafel», в состав которого включено более 900 продовольственных банков, бесплатно перераспределяющих пищевые продукты малообеспеченному населению, численность которого составляет более 1,5 млн человек. В США некоммерческая организация «Feeding America» объединяет целую сеть (более 200) банков и фондов продовольствия. Во Франции законодательство предусматривает передачу непроданных продуктов питания благотворительным организациям, обеспечивающим доставку продовольствия нуждающимся.

Следует также отметить, что за рубежом распространена практика предоставления налоговых льгот предприятиям пищевой торговли и общественного питания при их участии в благотворительности. Например, в США затраты на благотворительность (до $10 \%$ дохода) могут быть учтены в расходах компании, уменьшая сумму налогооблагаемой прибыли.

Такая политика государства обеспечивает заинтересованность бизнеса в предоставлении помощи малообеспеченным группам населения, а также в поддержке фондов продовольствия. Учитывая обострение проблемы бедности, в России также представляется целесообразным применение практики снижения налогового бремени коммерческих компаний, обеспечивающих бесплатно продуктами питания малоимущих. Привлечение ресурсов бизнес-структур обеспечит снижение остроты проблемы бедности и, соответственно, недоедания без дополнительной нагрузки на федеральный, региональные и местные бюджеты. 


\section{Предложения по привлечению российских коммерческих компаний для обеспечения продовольствием малоимущего населения}

Во многих странах мира пищевые продукты, срок годности которых подходит к концу, подлежат перераспределению в пользу малоимущих через благотворительные учреждения (в частности, банки продовольствия). В России подобная практика не получила широкого распространения, и данная проблема только частично решается посредством деятельности благотворительных организаций.

Наиболее известной организацией в РФ является фонд продовольствия «Русь», созданный в 2012 году. В настоящее время через данный фонд в пользу малоимущего населения перераспределяется до 6 тыс. тонн пищевых продуктов в год [Фонд продовольствия «Русь», 2021]. В рамках деятельности фонда сформирована система контроля качества продуктов питания. Однако масштабы деятельности указанного фонда, а также других благотворительных организаций существенно ограничены по следующим причинам:

1. Отсутствие складских помещений, оборудованных для хранения продуктов, значительно ограничивает время доведения пищи, переданной на благотворительность, до потребителя. Обычно продовольственные фонды ограничиваются быстрыми перевозками продовольствия со складов коммерческих предприятий до пунктов выдачи малоимущим.

2. Недостаток средств для осуществления перевозок. Фонд «Русь» (как и другие благотворительные организации) осуществляет перевозки за счет средств из пожертвований, которых может оказаться недостаточно для быстрых доставок скоропортящихся продуктов в пункт выдачи.

3. Необходимость передачи продовольствия населению через другие благотворительные организации (центры социального обслуживания, приходы храмов и др.). Такая практика затрудняет проведение контроля за распределением пищевых продуктов.

Бесплатная раздача продовольственных товаров с истекающим сроком годности магазинами или предприятиями общественного питания в РФ не одобряется. Согласно позиции Роспотребнадзора, подобная практика не позволяет обеспечить эффективный контроль качества и безопасности пищи. Поэтому в России часто пищевые продукты после истечения срока их годности просто утилизируются. При этом утилизация производится за счет предприятий, вынужденных нести дополнительные затраты.

Со стороны российских ученых-экономистов, а также предпринимателей было много практических рекомендаций по урегулированию данной проблемы. Например, при магазинах предлагалось открывать специальные отделы для бесплатной раздачи пищевых товаров за день до истечения их срока годности.

Однако следует учитывать, что в настоящее время особую значимость приобретает не просто распространение футшеринга, a возможность передачи продовольственных продуктов с истекающим сроком годности малоимущим. Поэтому в России целесообразна реализация масштабной программы продовольственных талонов, инициируемая государством и предполагающая активное участие предприятий общественного питания и торговли.

В отличие от практики, распространенной в развитых странах, финансирующих подобные программы за счет средств из государственных бюджетов, следует активно задействовать ресурсы торговых компаний, а также предприятий общественного питания.

Как известно, привлечение крупных бизнес-структур в государственные программы по искоренению голода и недоедания приносило положительные результаты в странах с развивающимися экономиками (например, в Бразилии и Китае).

На уровне государства возможна организация распределения продовольственных талонов среди малоимущего населения. Предлагаемая программа должна охватывать российское население с доходами, не превышающими величину прожиточного минимума. Предоставление талонов необходимо осуществлять в соответствии со сведениями, которыми располагают органы социальной защиты (наравне с пособиями), и по схожим критериям. 
Особенно эффективно для реализации программы продовольственных талонов привлечение торговых сетей крупных компаний-ритейлеров. Согласно оценке специалистов Ассоциации компаний розничной торговли (АКРТ), потери продуктов питания предприятий, входящих в состав организации, иногда достигают более 700 тыс. тонн в год. Примерно $25 \%$ утилизируемого продовольствия составляют молочные продукты, колбасные и кондитерские изделия, а также бакалея; около $30 \%$ - мясо, птица и рыба; 45 \% - овощи и фрукты [Ассоциация компаний ..., 2021].

Создание пунктов выдачи пищевых продуктов с истекающим сроком годности возможно непосредственно на территориях супермаркетов, которые часто располагаются в разных районах крупных и небольших городов. Возможность бесплатного получения продуктов питания недалеко от места жительства особенно важна для пожилых людей и инвалидов, доля которых в группе малоимущего населения достаточно велика.

Наличие в магазинах специально оборудованных складских помещений обеспечит сохранность продовольствия до выдачи предъявителям талонов, а развитая логистика - возможность доставки продуктов питания с истекающим сроком годности в другие районы городов и даже регионов.

Формирование пунктов выдачи в супермаркетах позволит государственным контролирующим структурам осуществлять мониторинг качества и количества предоставляемых малоимущему населению пищевых продуктов.

Особое внимание следует уделить организации передачи малоимущим продуктов с истекающим сроком годности небольшими магазинами, точками общественного питания и предприятиями пищевой промышленности. В среднем по России практически ежегодно выбрасывается около 17 млн тонн продовольствия на сумму 1,6 трлн рублей [Информационное издание ..., 2019]. Формирование благоприятных условий приумножит возможности перераспределения продовольствия нуждающимся через российские продовольственные фонды. Целесообразно переориентировать общественные продовольственные фонды на сотрудничество с небольшими коммерческими предприятиями (реализаторами про- дуктов питания), а также на точки общепита. В России уже сформирован реестр общественных организаций, работа с которыми обеспечивает определенные налоговые льготы предпринимательским структурам (в частности, по налогу на прибыль).

Современные системы оповещения позволят обеспечить быструю передачу информации населению, а также получать сведения (посредством обратной связи) о готовности забрать продукты питания в указанном пункте выдачи. Один сотовый телефон на семью в настоящее время имеют даже люди, живущие за чертой бедности. Соответственно, существует возможность создания информационных сетей, охватывающих крупные компании, реализующие продовольствие (контролируемые государственными структурами), а также небольшие продовольственные предприятия и точки общественного питания (осуществляющие благотворительную деятельность через общественные фонды). Технологии уведомления могут разрабатываться с учетом зарубежного опыта. Например, в США для передачи сведений благотворительным организациям используется технология уведомления push (на основе программного продукта PointCast).

Условия предложенной программы должны быть определены с учетом зарубежного опыта, который следует адаптировать к российской специфике, а также к текущей ситуации в стране. В развитых странах продовольственные талоны малоимущим выдаются на определенные суммы, а программы помощи финансируются из государственных бюджетов. В России предлагается предоставлять малоимущим талоны на получение продуктов питания в определенных объемах (без указания стоимости, так как цены на продовольственные товары с истекающим сроком годности могут существенно различаться даже в пределах одной товарной группы).

Согласно исследованию экспертного совета по проблемам продовольственной безопасности, сформированного фондом «Русь» и компанией $\mathrm{PwC}$, формирование благоприятных условий для благотворительности может обеспечить малоимущим значительную продовольственную помощь. Только со стороны крупных компаний-ритейлеров российскому населению с доходами ниже прожиточного минимума мо- 
жет предоставляться около пяти килограммов продуктов питания на человека в месяц. По результатам исследования экспертного совета, можно предварительно определить объем выдачи по талону продуктов питания (5 кг). В дальнейшем установленные объемы можно корректировать с учетом изменения продовольственной ситуации в стране, а также возможностей государства и бизнес-структур. При возникновении проблем возможно частичное возмещение стоимости пищевых продуктов, предоставляемых по талонам, из средств бюджетов разных уровней. При этом нагрузка на бюджеты будет существенно ниже, чем при проведении программы продовольственных талонов полностью за счет государства (как в большей части развитых стран).

Конечно, предложенная программа не лишена недостатков. Например, будет сложно планировать номенклатуру и объемы каждого из выдаваемых товаров. Предложение коммерческих предприятий будет определяться наличием и объемами пищевых продуктов с истекающим сроком годности. Однако получение дополнительных пяти килограммов пищевых продуктов в месяц на каждого человека позволит сэкономить денежные средства для покупки недостающих продовольственных товаров или для осуществления других расходов. Программа продовольственных талонов обеспечит сокращение численности россиян, страдающих от бедности и недоедания.

В настоящее время проблемы бедности и недоедания в России обострились из-за экономического спада, вызванного ограничением предпринимательской деятельности на время пандемии. Поэтому реализация предложенной программы продовольственных талонов особенно актуальна, так как обеспечит возможность поддержки малоимущего населения за счет неиспользуемых ресурсов коммерческих структур.

\section{Комплекс \\ стимулирующих мер для привлечения коммерческих компаний к обеспечению продовольствием малоимущих}

Роль коммерческих структур в системе поддержки малоимущего населения может существенно возрасти при формировании со- ответствующих условий. Для стимулирования активности компаний необходимы меры как налогового стимулирования, так и налоговых ограничений.

В настоящее время объемы бесплатно передаваемых малоимущим продовольственных продуктов с истекающим сроком годности ограничены. Одной из основных причин этого является несовершенство российского налогового законодательства. При передаче продовольствия общественным организациям, обеспечивающим перераспределение продуктов питания в пользу нуждающихся, у коммерческих предприятий возникают дополнительные налоговые обязательства (см. табл. 2).

В 2020 г. Государственной думой был принят закон, обеспечивающий для предприятий возможность частично учитывать в расходах, уменьшающих налогооблагаемую прибыль, стоимость товаров, переданных на благотворительность. При этом сумма, уменьшающая налогооблагаемую прибыль, ограничена 1 \% выручки компании (ст. 265, пп. 19.6 НК РФ).

Положения указанной статьи применимы только при передаче товаров в общественные организации, введенные в специально сформированный государственный реестр. Данные ограничения предусмотрены для предотвращения схем по уходу от налогов.

Конечно, изменение налогового законодательства обеспечивает более благоприятные условия для компаний, передающих продукты питания на благотворительность. Однако следует принимать во внимание, что продовольствие относится к категории товаров, рациональное использование которых может существенно улучшить положение малоимущего населения.

Согласно оценке экспертов АКРТ, объемы пищевых отходов торговых сетей ежегодно составляют от 2 до $6 \%$ товарооборота [Ассоциация компаний ..., 2021]. Следует учитывать, что в соответствии с налоговым законодательством расходы в виде стоимости пищевых продуктов при их утилизации по истечению срока годности считаются экономически обоснованными и, соответственно, сокращают налогооблагаемую прибыль (ст. 264, п. 1, пп. 49 НК РФ). 


\section{Обязательства по налогообложению при утилизации и передаче} продуктов питания на благотворительность

\begin{tabular}{|c|c|c|}
\hline Обязательства по налогам & НДС & Налог на прибыль \\
\hline \multirow[t]{2}{*}{$\begin{array}{l}\text { Утилизация продуктов } \\
\text { питания по истечению } \\
\text { срока годности }\end{array}$} & $\begin{array}{l}\text { Списание товара (в том числе продо- } \\
\text { вольственного назначения) не является } \\
\text { операцией, облагаемой } \\
\text { (ст. } 146 \text { НК РФлогом }\end{array}$ & $\begin{array}{l}\text { При утилизации товаров (в том числе продо- } \\
\text { вольственного назначения) у организации не } \\
\text { возникает доходов, учитываемых при форми- } \\
\text { ровании налоговой базы по налогу на при- } \\
\text { быль организаций (ст. } 248 \text { НК РФ) }\end{array}$ \\
\hline & $\begin{array}{l}\text { В перечне ситуаций, требующих вос- } \\
\text { становить налог (п. } 3 \text { ст. } 170 \text { НК РФ), } \\
\text { списание товара (в том числе продо- } \\
\text { вольственного назначения) не поиме- } \\
\text { новано }\end{array}$ & $\begin{array}{l}\text { Расходы в виде стоимости товаров с истек- } \\
\text { шим сроком реализации и расходы по их } \\
\text { уничтожению (в случае, если таковые имеют- } \\
\text { ся) являются для организации экономически } \\
\text { обоснованными и могут быть учтены в целях } \\
\text { налогообложения прибыли (ст. 264, п. } 1 \text {, } \\
\text { пп. } 49 \text { НК РФ) }\end{array}$ \\
\hline \multirow[t]{2}{*}{$\begin{array}{lr}\text { Передача } & \text { продуктов } \\
\text { питания на } & \text { благотво- } \\
\text { рительность } & \end{array}$} & $\begin{array}{l}\text { Не подлежит налогообложению пере- } \\
\text { дача товаров безвозмездно (в том чис- } \\
\text { ле пищевых продуктов) в рамках бла- } \\
\text { готворительной деятельности, за ис- } \\
\text { ключением подакцизных товаров } \\
\text { (ст. } 149, \text { п. } 3 \text {, пп. } 12 \text { НК РФ) }\end{array}$ & $\begin{array}{l}\text { При безвозмездной передаче товаров (в том } \\
\text { числе продовольственного назначения) у пе- } \\
\text { редающей стороны не возникает доходов, } \\
\text { учитываемых при формировании налоговой } \\
\text { базы по налогу на прибыль организаций } \\
\text { (ст. } 248 \text { НК РФ) }\end{array}$ \\
\hline & $\begin{array}{l}\text { Суммы НДС, предъявленные продав- } \\
\text { цом товаров, передаваемых в рамках } \\
\text { благотворительности, должны быть } \\
\text { учтены в стоимости и не подлежат вы- } \\
\text { чету. Если товар изначально был при- } \\
\text { обретен для деятельности, облагаемой } \\
\text { НДС, и налог был принят к вычету, то } \\
\text { при его передаче ранее принятый к } \\
\text { вычету НДС подлежит восстановле- } \\
\text { нию (ст. } 170, \text { п. } 3 \text {, пп. } 2 \text {, абз. } 1 \text { НК РФ) }\end{array}$ & $\begin{array}{l}\text { Расходы в виде стоимости товаров (включая } \\
\text { продукты питания), безвозмездно переданных } \\
\text { некоммерческим организациям, включенным } \\
\text { в реестр социально ориентированных неком- } \\
\text { мерческих организаций, для целей налогооб- } \\
\text { ложения признаются в размере, не превы- } \\
\text { шающем } 1 \text { \% выручки от реализации (ст. 265, } \\
\text { п. 1, пп. } 19.6 \text { НК РФ) }\end{array}$ \\
\hline
\end{tabular}

Примечание. Составлено автором по: [Налоговый кодекс Российской Федерации].

Кроме того, при бесплатной передаче продуктов питания социально ориентируемым общественным организациям увеличиваются суммы платежей по НДС. Согласно законодательству, передача продовольствия на благотворительность не подлежит налогообложению НДС (ст. 149, п. 3, пп. 12 НК РФ). Однако, если изначально товары были приобретены для деятельности, облагаемой НДС, налог, принятый ранее по ним к вычету, подлежит восстановлению и уплате (ст. 170, п. 3, пп. 2, абз. 1 НК РФ). Конечно, следует принимать во внимание, что при этом на сумму восстановленного НДС сокращается налогооблагаемая прибыль предприятия. Однако сумма подлежащего к уплате возвратного НДС значительно превышает экономию по налогу на прибыль.

Списание пищевых продуктов по истечению срока их годности также не подлежит налогообложению НДС. Однако при утилизации товаров восстановление налога, ранее при- нятого к вычету, не предусмотрено (ст. 170, п. 3 НК РФ).

Таким образом, даже после принятых изменений налогового законодательства предпринимательским структурам по-прежнему выгоднее утилизировать значительные объемы продовольственных товаров (дождавшись истечения срока годности), чем передавать в социально ориентируемые организации для перераспределения малоимущим.

В настоящее время передача продовольственных продуктов на благотворительность обходится российским компаниям значительно дороже, чем утилизация. По оценке специалистов, расходы на погашение обязательств по налогам при передаче пищевых продуктов на благотворительность на 30-40 \% превышают затраты по утилизации [Ассоциация компаний ..., 2021].

Предложения отменить восстановление возвратного НДС при передаче пищевых про- 
дуктов с истекающим сроком годности на благотворительность уже вносились на рассмотрение в Государственную думу российскими экономистами. Однако в условиях обострения продовольственной ситуации необходимы более действенные меры.

Во-первых, компаниям, участвующим в предложенной государственной программе продовольственных талонов или передающим пищевые продукты в благотворительные фонды, следует предоставить возможность учитывать стоимость данных продуктов в расходах, уменьшающих налогооблагаемую прибыль, в полном объеме. Осуществление бизнес-структурами мошеннических схем при расширении возможностей государственного контроля в рамках программы продовольственных талонов станет практически невозможным.

Во-вторых, в налоговое законодательство об исчислении и уплате НДС необходимо внести изменения. Конечно, целесообразно отменить восстановление НДС при передаче пищи с истекающим сроком годности малоимущим по программе продовольственных талонов или через общественные организации. Кроме этого, необходимо ввести требование о восстановлении принятого ранее к вычету НДС при утилизации продовольствия (в том числе при истечении срока годности). Соответственно, это будет стимулировать предприятия, занимающиеся реализацией пищевых товаров, активно принимать меры по своевременной передаче продуктов питания с истекающим сроком годности нуждающимся.

При внесении предлагаемых изменений в налоговое законодательство передача продовольственных товаров малоимущим через программу продовольственных талонов или через общественные организации станет выгоднее, чем утилизация.

Внесение предлагаемых изменений в налоговое законодательство обеспечит формирование благоприятных условий для реализации программы продовольственной помощи малоимущим без дополнительной нагрузки на государственный бюджет, сокращение затрат бизнес-структур, связанных с утилизацией просроченных пищевых продуктов, а также уменьшение объемов продовольственных отходов.

\section{Выводы}

Предложенные в данной статье меры должны стать дополнением к программам, разработанным в соответствии с положениями Доктрины продовольственной безопасности 2020 г. и направленным на повышение уровня самообеспечения, поддержку российского агропромышленного комплекса и обеспечение возможности противостоять внешним рискам. Для обеспечения экономической доступности пищи всему населению страны (в том числе малоимущему) недостаточно повышения эффективности аграрного производства и уровня самообеспеченности наиболеезначимыми продуктами питания. Решению проблемы бедности и недоедания должно способствовать также сокращение неравенства. Признание права человека на доступ к достаточным объемам пищи является результатом мобилизации усилий гражданского общества.

Крупные предпринимательские структуры обладают значительными ресурсами для помощи наиболее уязвимым группам населения. Поэтому значение участия коммерческих компаний в государственных стратегиях по решению проблемы бедности и недоедания нельзя недооценивать. Во многих странах частные предприятия проявляют интерес к государственным проектам, связанным с обеспечением продовольствием малоимущих.

Повышение роли государства, активное привлечение коммерческих компаний, а также расширение деятельности социально ориентированных общественных организаций - все это позволит обеспечить доступность пищи в необходимых объемах для всего населения страны.

\section{СПИСОК ЛИТЕРАТУРЫ}

Ассоциация компаний розничной торговли : [сайт]. - Электрон. текстовые дан. - Режим доступа: http:/www.acort.ru/media-tsentr/tsifry-i-faktyriteyla/ (дата обращения: 11.02.2021). - Загл. с экрана.

Буланов, С. Ю. Социально-экономические угрозы экономической безопасности России и европейский опыт их предотвращения : монография. - М. : Юго-Восток-Сервис, 2007. - 91 с.

Ибрагимов, М.-Т. А. Методические подходы к оценке состояния продовольственной безопасно- 
сти региона / М.-Т. А. Ибрагимов, С. В. Дохолян // Региональные проблемы преобразования экономики. - 2010. - № 4. - Электрон. текстовые дан. - Режим доступа: http:// www.rppe.ru/wp-content/uploads/2012/12/ ibragimov-m-ta-dokholyan-sv.pdf (дата обращения: 11.02.2021). - Загл. с экрана.

Информационное издание Министерства сельского хозяйства Российской Федерации «Продовольственная безопасность, самообеспеченность России по критериям товаров из продовольственной потребительской корзины на ближайшие годы». - М. : ФГБНУ «Росинформагротех», 2019. - 256 с. - Электрон. текстовые дан. - Режим доступа: https:// rosinformagrotech.ru/data/download/66normativnye-dokumenty-spravochniki-katalogi/ 1362 -prodovolstvennaya-bezopasnostsamoobespechennost-rossii-po-kriteriyamtovarov-iz-prodovolstvennoj-potrebitelskojkorziny-na-blizhajshie-gody-2019 (дата обращения: 11.02.2021). - Загл. с экрана.

Коваленко, Н. Я. Экономическое регулирование рыночных отношений в сельском хозяйстве / Н. Я. Коваленко // Экономика сельскохозяйственных и перерабатывающих предприятий. -2013 . - № 5. - С. 22-27.

Кудряшова, А. А. Продовольственная безопасность: показатели, критерии, категории и масштабы / А. А. Кудряшова // Пищевая промышленность. -2009 . - № 12. - С. 42-45.

Международный исследовательский институт продовольственной политики : [сайт ]. - Электрон. текстовые дан. - Режим доступа: https:// www.globalhungerindex.org/de/russia.html (дата обращения: 11.02.2021). - Загл. с экрана.

Налоговый кодекс Российской Федерации (НК РФ). - Электрон. текстовые дан. - Режим доступа: https://base.garant.ru/10900200/ (дата обращения: 11.02.2021). - Загл. с экрана.

Носов, В. В. Технологическая модернизация пищевой и перерабатывающей промышленности в аспекте обеспечения продовольственной безопасности России / В. В. Носов, Н. Ю. Чернегов // Modern Science. - 2020. - № 2-1. C. $82-91$.

Основы экономической безопасности (государство, регион, предприятие, личность) / под ред. Е. А. Олейникова. - М. : Бизнес-школа «Интел-синтез», 1997. - 246 с.

Серова, Е. В. Перспективы реформирования агропромышленной политики России / Е. В. Серова // Общество и экономика. - 2004. - № 7-8. С. 254-302.

Указ Президента РФ от 21 января 2020 г. № 20 «Об утверждении Доктрины продовольственной безопасности Российской Федерации». Электрон. текстовые дан. - Режим доступа: https://www.garant.ru/products/ipo/prime/doc/ 73338425/ (дата обращения: 11.02.2021). - Загл. с экрана.

Федеральная служба государственной статистики : [сайт ]. - Электрон. текстовые дан. - Режим доступа: https://rosstat.gov.ru/folder/13723?print=1 (дата обращения: 11.02.2021). - Загл. с экрана.

Фонд продовольствия «Русь» : [сайт ]. - Электрон. текстовые дан. - Режим доступа: https:// foodbankrus.ru/o-nas/rezultaty-raboty/ (дата обращения: 11.02.2021). - Загл. с экрана.

Хромов, Ю. С. Продовольственная безопасность страны: уроки кризиса / Ю. С. Хромов // Международный сельскохозяйственный журнал. 1999. - № 1. - С. 28-35.

Черняков, Б. А. Российское сельское хозяйство и мировой рынок / Б. А. Черняков // Экономика сельскохозяйственных и перерабатывающих предприятий. - 1998. - № 1. - С. 44-46.

Шагайда, Н. И. Продовольственная независимость и продовольственная безопасность России с точки зрения правил ВТО / Н. И. Шагайда // Экономическое развитие России. - 2015. - Т. 22, № 2. - C. 59-62.

Food and Agriculture Organization of the United Nations. - Electronic text data. - Mode of access: http://www.fao.org/platform-food-loss-waste/ food-loss/introduction/en/ (date of access: 11.02.2021). - Title from screen.

\section{REFERENCES}

Assotsiatsiya kompaniy roznichnoy torgovli [Association of the Retailing Companies]. URL: http://www.acort.ru/media-tsentr/tsifry-i-faktyriteyla (accessed 11 February 2021).

Bulanov S.Yu. Sotsial'no-ekonomicheskie ugrozy ekonomicheskoy bezopasnosti Rossii $i$ evropeyskiy opyt ikh predotvrashcheniya: monografiya [Socio-Economic Threats to the Economic Security of Russia and the European Experience of Their Prevention. Monograph]. Moscow, Yugo-Vostok-Service, 2007. 91 p.

Ibragimov M.-T.A., Dokholyan S.V. Metodicheskie podkhody $k$ otsenke sostoyaniya prodovol'stvennoy bezopasnosti regiona [Methodological Approaches to the Assessment of Food Security of the Region]. Regional'nye problemy preobrazovaniya ekonomiki [Regional Problems of Transforming the Economy], 2010, no. 4. URL: http://www.rppe.ru/wp-content/ uploads/2012/12/ibragimov-m-ta-dokholyansv.pdf (accessed 11 February 2021). 
Informatsionnoe izdanie Ministerstva sel'skogo khozyaystva Rossiyskoy Federatsii "Prodovol'stvennaya bezopasnost', samoobespechennost' Rossii po kriteriyam tovarov iz prodovol'stvennoy potrebitel'skoy korziny na blizhayshie gody" [Information Publication of the Ministry of Agriculture of the Russian Federation "Food Security, SelfSufficiency of Russia According to the Criteria of Goods From the Food Consumer Basket for the Coming Years"]. Moscow, FGBNU "Rosinformagrotekh", 2019.256 p. URL: https:// rosinformagrotech.ru/data/download/66normativnye-dokumenty-spravochniki-katalogi/ 1362 -prodovolstvennaya-bezopasnostsamoobespechennost-rossii-po-kriteriyamtovarov-iz-jdov-olstorstoriyam-tovarov-iz-jdovolstotorov na-blizhajshie-gody-2019 (accessed 11 February 2021).

Kovalenko N.Ya. Ekonomicheskoe regulirovanie rynochnykh otnosheniy v sel'skom khozyaystve [Economic Regulation of Market Relations in Agriculture]. Ekonomika sel'skokhozyaystvennykh i pererabatyvayushchikh predpriyatiy [Economics of Agricultural and Processing Enterprises], 2013, no. 5, pp. 22-27.

Kudryashova A.A. Prodovol'stvennaya bezopasnost': pokazateli, kriterii, kategorii i masshtaby [Food Security: Indicators, Criteria, Categories and Scales]. Pishchevaya promyshlennost' [Food Industry], 2009, no. 12, pp. 42-45.

Mezhdunarodnyy issledovatel'skiy institut prodovol 'stvennoy politiki [International Food Policy Research Institute]. URL: https:// www.globalhungerindex.org/de/russia.html (accessed 11 February 2021).

Nalogovyy kodeks Rossiyskoy Federatsii (NK RF) [Tax Code of the Russian Federation]. URL: https://base.garant.ru/10900200 (accessed 11 February 2021).

Nosov V.V., Chernegov N.Y. Tekhnologicheskaya modernizatsiya pishchevoy i pererabatyvayushchey promyshlennosti $\mathrm{v}$ aspekte obespecheniya prodovol'stvennoy bezopasnosti Rossii [Technological Modernization of the Food and Processing Industry in the Aspect of Ensuring Food Security in Russia]. Modern Science, 2020, no. 2-1, pp. 82-91.
Oleinikov E.A., ed. Osnovy ekonomicheskoy bezopasnosti (gosudarstvo, region, predpriyatie, lichnost') [Fundamentals of Economic Security (State, Region, Enterprise, Personality)]. Moscow, Biznes-shkola "Intel-sintez", 1997. 246 p.

Serova E.V. Perspektivy reformirovaniya agropromyshlennoy politiki Rossii [Prospects for Reforming the Agroindustrial Policy of Russia]. Obshchestvo i ekonomika [Society and Economics], 2004, no. 7-8, pp. 254-302.

Ukaz Prezidenta RF ot 21 yanvarya 2020 g. № 20 «Ob utverzhdenii Doktriny prodovol'stvennoy bezopasnosti Rossiyskoy Federatsii» [Decree of the President of the Russian Federation of January 21, 2020 No. 20 "On the Approval of the Doctrine for Food Security of the Russian Federation"]. URL: https://www.garant.ru/ products/ipo/prime/doc/73338425 (accessed 11 February 2021).

Federal'naya sluzhba gosudarstvennoy statistiki [Federal State Statistics Service]. URL: https:// rosstat.gov.ru/folder/13723?print=1 (accessed 11 February 2021).

Fond prodovol'stviya «Rus'» [Foodbank Rus]. URL: https://foodbankrus.ru/o-nas/rezultaty-raboty (accessed 11 February 2021).

Khromov Y.S. Prodovol'stvennaya bezopasnost' strany: uroki krizisa [Food Security of the Country: Lessons of the Crisis]. Mezhdunarodnyy sel'skokhozyaystvennyy zhurnal [International Agricultural Journal],1999, no. 1, pp. 28-35.

Chernyakov B.A. Rossiyskoe sel'skoe khozyaystvo i mirovoy rynok [Russian Agriculture and the World Market]. Ekonomika sel'skokhozyaystvennykh $i$ pererabatyvayushchikh predpriyatiy [Economics of Agricultural and Processing Enterprises], 1998, no. 1, pp. 44-46.

Shagayda N.I. Prodovol'stvennaya nezavisimost' i prodovol'stvennaya bezopasnost' Rossii s tochki zreniya pravil VTO [Food Independence and Food Security of Russia From the WTO Rules Point of View]. Ekonomicheskoe razvitie Rossii [Economic Development of Russia], 2015, vol. 22, no. 2, pp. 59-62.

Food and Agriculture Organization of the United Nations. URL: http:/www.fao.org/platformfood-loss-waste/food-loss/introduction/en (accessed 11 February 2021). 


\section{УПРАВЛЕНИЕ ЭКОНОМИЧЕСКИМ РАЗВИТИЕМ}

\section{Information About the Authors}

Aleksandr V. Ishkhanov, Doctor of Sciences (Economics), Professor, Department of World Economy and Management, Kuban State University, Stavropolskaya St, 149, 350040 Krasnodar, Russian Federation, alexander@ishkhanov.ru, https://orcid.org/0000-0002-0157-1871

Elena F. Linkevich, Doctor of Sciences (Economics), Associate Professor, Professor of Department of World Economy and Management, Kuban State University, Stavropolskaya St, 149, 350040 Krasnodar, Russian Federation, alins@list.ru, https://orcid.org/0000-0002-2760-7713

\section{Информация об авторах}

Александр Владимирович Ишханов, доктор экономических наук, профессор, профессор кафедры мировой экономики и менеджмента, Кубанский государственный университет, ул. Ставропольская, 149, 350040 г. Краснодар, Российская Федерация, alexander@ishkhanov.ru, https://orcid.org/0000-0002-0157-1871

Елена Федоровна Линкевич, доктор экономических наук, доцент, профессор кафедры мировой экономики и менеджмента, Кубанский государственный университет, ул. Ставропольская, 149, 350040 г. Краснодар, Российская Федерация, alins@list.ru, https://orcid.org/0000-0002-2760-7713 